Tersedia online di: http://ejournal-balitbang.kkp.go.id/index.php/JP
e-mail:jurnalpari@gmail.com
JURNAL PARI
Volume 3 Nomor 1 Juli 2017
-ISSN: 2502-0730
e-ISSN : 2549-0133

\title{
IMPLEMENTASI SISTEM PENGELOLAAN KEARSIPAN YANG EVEKTIF PADA UNIT PELAKSANA TEKNIS SEKOLAH USAHA PERIKANAN MENENGAH SORONG LINGKUP KEMENTERIAN KELAUTAN DAN PERIKANAN
}

Implementation of An Effective Archive Management System At Technical Implementation Units Secondary Fishery Business School of Sorong Scope Ministry of Marine Affairs and Fisheries

\author{
ARFA FAKAUBUN \\ Sekolah Usaha Perikanan Menengah Sorong \\ Diterima tanggal : 20 Maret 2017 diterima setelah perbaikan : 8 Mei 2017 disetujui terbit : 29 Juni 2017
}

\section{ABSTRAK}

Kearsipan merupakan bagian yang tidak terpisahkan dari Tata Naskah Dinas, kerena Tata Naskah Dinas merupakan Pedoman Umum dalam pelaksanaan Tugas dan Fungsi Administrasi Perkantoran. dan sangat mendukung kelancaran arus komunikasi kedinasan antar instansi Pemerintah dalam pelaksanaan penyelenggaraan Pemerintahan dan Pembangunan serta Pelayanan Publik. Kearsipan dan Tata Naskah Dinas di Sekolah Usaha Perikanan Menengah (SUPM) Sorong Berpedoman pada Peraturan Menteri Kelautan dan Perikanan Nomor 53/PERMEN-KP/2014 tentang Kearsipan dan Nomor 52/PERMEN-KP/2014 tentang Pedoman Umum Tata Naskah Dinas. Dalam Pengelolaan kearsipan yang baik dan benar disetiap instansi, Pemerintah berkewajiban mengembangkan kwantitas dan kwalitas Sumber Daya Manusia yang memiliki kompetensi dan profesionalitas dibidang kearsipan. Pengelolaan Arsip terdiri dari Arsip Aktif dan Arsip Inaktif, pencipta arsip secara baik dan benar sesuai dengan Peraturan Perundang-undangan yang berlaku dan pengelolaan kearsipan dilaksanakan untuk menjamin ketersediaan arsip dalam penyelenggaraan kegiatan sebagai bahan akuntabilitas kinerja dan alat bukti yang sah berdasarkan suatu sistem penciptaan arsip. Undang-Undang Kearsipan Nomor 43 Tahun 2009 bahwa sistem kearsipan diperluhkan penyelengaraan kearsipan yang sesuai dengan prinsip kaidah dan standar kearsipan sebagai mana dibutuhkan oleh suatu sistem penyelenggaraan kearsipan yang efektif, terpadu dan terjamin kerahasiaannya.

Kata Kunci : Kearsipan merupakan alat bukti yang sah.

\section{ABSTRACT}

Archive is an integral part of the Official scripts, because the Official scripts are General Guidelines for the implementation of tasks and administrative functions. This strongly supports the official communication among governent agencies in the implementation of governance, development and public Service. Archive and the Official scripts in Sekolah Usaha Perikanan Menengah (SUPM) Sorong based on the Kementerian Kelautan dan Perikanan Number : 53 /PERMEN-KP/2014 on Archives and Number : 52 /PERMEN-KP/2014 on general guidelines for the Official scripts. The archival management is good and true in evary instance, the goverment should be develop the quality and quantity of human resource who have the competence and professionalism in the field of archives. Archive file management were composed of active and inactive archives, archive creator properly and correctly in accordance with the laws in force and management legislation implemented to ensure availability of archive records in the implementation of the activities as a performance accountability and legal evidence is based on a system of archive creation. Legislation number. 43 on 2009 that filing that the archive system accordance with the rules and principles of archive standards as reguired by the implementation of a system archival efective, integrated and confidential.

\section{Keywords : Archives is the valid evidence}




\section{PENDAHULUAN}

Dunia Kearsipan sebagai salah satu bidang dalam kehidupan bermasyarakat, lembaga dan bernegara yang tidak luput dari perubahan. Arsip yang berada dibeberapa tempat, awalnya secara umum dapat dimaknai arsip sebagai tumpukan kertas, seperti hasil kegiatan yang sudah tidak digunakan lagi dimana biasanya disimpan di dalam kardus atau karung bekas. Dan saat ini besar tuntutan akan perubahan dari kondisi tersebut, bahkan arsip sudah menjelma dalam berbagai bentuk media simpan termasuk arsip elektronik. Besar tuntutan bahwa arsip dapat di sajikan kembali bagi publik baik untuk keperluan penelitian dalam rangka penyelesaian studi, sebagaimana tercantum dalam Pembukaan Undang-Undang Dasar Negara Republik Indonesia Tahun 1945 bahwa Arsip merupakan memori kolektif yang memuat informasi pemerintahan dan pembangunan antara lain sebagai bukti pertanggung jawaban Nasional, Identitas dan Jati Diri Bangsa, Warisan Budaya Bangsa yang bernilai tetap/permanen, dengan meningkatnya aktivitas pemerintahan dan pembangunan, kemajuan teknologi informasi, serta aktivitas organisasi dalam melaksanakan tugas dan fungsi maupun berakibat pada meningkatnya jumlah arsip yang tercipta. Sesuai dengan Undang-Undang Nomor 43 Tahun 2009 tentang kearsipan bahwa Kearsipan adalah hal-hal yang berkenaan dengan arsip. Arsip merupakan rekaman kegiatan atau peristiwa dalam berbagai bentuk dan media sesuai dengan perkembangan teknologi informasi dan komunikasi yang dibuat dan diterima oleh lembaga negara, pemerintah daerah, lembaga pendidikan, perusahaan, organisasi politik, organisasi kemasyarakat, berbangsa dan bernegara.

Berkaitan dengan hal-hal tersebut diatas, maka Sekolah Usaha Perikanan Menengah (SUPM) Sorong telah Mengimplementasikan Kearsipan secara baik dan benar yang berpedoman pada Peraturan Menteri Kelautan dan Perikanan tentang Tata Naskah Dinas dan Kearsipan, karena Sekolah Usaha Perikanan Menengah (SUPM) Sorong merupakan Sekolah Kejuruan dibidang Perikanan yang berada di bawah naungan Kementerian Kelautan dan Perikanan.

\section{TINJAUAN PUSTAKA}

Kearsipan adalah Suatu proses penyimpanan arsip secara sistematika agar mudah ditemukan kembali, yang meliputi Penciptaan (pembuatan dan penerimaan), penyimpanan (filing) dan penemuan kembali (finding), penyelamatan (pengamanan, pemeliharaan dan perawatan) penyusutan arsip (pemindahan, penyerahan dan pemusnahan).

Kerasipan juga disebut sebagai hal-hal berkenang dengan arsip yang meliputi :

1. Arsip dinamis adalah arsip yang digunakan secara langsung dalam kegiatan penciptaan arsip dan disimpan selama jangka waktu tertentu

2. Arsip statis adalah arsip yang dihasilkan oleh pencipta arsip karena memiliki nilai guna kesejarahan, telah habis retensinya dan berketerangan dipermanenkan yang telah diverifikasi baik secara langsung maupun tidak langsung oleh Arsip Nasional Republik Indonesia dan/atau lembaga kearsipan.

3. Arsip aktif adalah arsip yang frekuensi penggunaannya tinggi dan/atau terus menerus

4. Arsip inakti adalah arsip yang frekuensi penggunaannya telah menurun

5. Arsip vital adalah arsip yang keberadaannya merupakan persyaratan dasar bagi kelangsungan operasional pencipta arsip, tidak dapat diperbaharui dan tidak tergantikan apabila rusak atau hilang

6. Arsip terjaga adalah arsip negara yang berkaitan dengan keberadaan dan kelangsungan hidup bangsa dan negara yang harus keutuhan, keamanan dan keselamatan

7. Arsip umum adalah arsip yang tidak termasuk dalam kategori arsip terjaga

8. Arsiparis adalah seseorang yang memiliki kompetensi di bidang kearsipan yang diperoleh melalui pendidikan formal dan/atau pendidikan dan pelatihan kearsipan serta mempuyai tugas dan fungsi dan tanggung jawab melaksanakan kearsipan.

9. Unit Kearsipan adalah satuan kerja pada pencipta arsip yang mempunyai tugas dan tanggung jawab dalam penyelenggaraan kearsipan

10. Unit Pengolah adalah satuan kerja pada pencipta arsip yang mempunyai tugas dan tanggung jawab mengolah semua arsip yang berkaitan dengan kegiatan penciptaan arsip dilingkungannya

11. Penyusutan arsip adalah kegiatan pengurangan jumlah arsip dengan cara pemindahan arsip inaktif dari unit pengolah 
keunit kearsipan, pemusnahan arsip yang tidak memiliki nilai guna dan penyerahan arsip statis kepada lembaga kearsipan.

Menurut Egunio Casanova (1867-1951) dalam bukunya Archivistica bahwa Arsip sebagai penambahan secara tertib dokumen-dokumen yang diciptakan selama kegiatannya oleh suatu lembaga atau perorangan, dan dipelihara untuk pelaksanaan tujuan politik, hukum, atau budaya oleh lembaga perorangan tersebut.

Menurut The Liang Gie dalam bukunya Administrasi perkantoran bahwa arsip adalah Kumpulan warkat yang disimpan secara teratur, berencana dan mempunyai suatu kegunaan agar setiap kali diperluhkan dapat cepat ditemukan kembali.

Menurut (Barlian 2013:15) bahwa Upaya untuk memenuhi hak warga negara, termasuk hak untuk berkomunikasi dan memperoleh informasi merupakan wujud pelaksanaan amanat konstitusi Unadng-Undang Dasar Tahun 1945 pasal 28 yang berbunyi "Setiap orang berhak untuk berkomunikasi dan memperoleh informasi untuk mengembangkan pribadi dan lingkungan sosialnya, serta berhak untuk mencari, memperoleh, memiliki, menyimpan, mengolah dan menyampaikan informasi dengan menggunakan segala jenis saluran yang tersedia".

(Sjachroni, 2015:17) Kepala Arsip Nasional Republik Indonesia bahwa mulai berkembangnya Sistem Kearsipan Nasional dengan memanfaatkan Teknologi Informasi dan Komunikasi yang dikenal sebagai Sistem Pengelolaan Arsip berbasis Teknologi Informasi dan Komunikasi (SIPATI).

Kemudian (Oetomo,2015:18) memperkenalkan arsip kepada Masyarakat. Pada masa ini pula lahirnya Undang-Undang Nomor 43 Tahun 2009 tentang Kearsipan yang menggantikan UndangUndang Nomor 7 Tahun 1971, perubahan besar terlihat dari pengertian arsip, dimana dalam UndangUndang Nomor 7 Tahun 1971 yang dimaksud dengan arsip adalah naskah-naskah, sedangkan dalam Undang-Undang Nomor 43 Tahun 2009 arsip adalah rekaman kegiatan dalam segalah bentuk dan media.

Menurut Djoko undang-undang baru ini membawah perubahan yang seknifikan dalam dunia kearsipan di Indonesia dimana undang-undang nomor 7 tahun 1971 lebih fokus pada arsip statis, sedangkan Undang-Undang Nomor 43 Tahun 2009 tidak hanya fokus kepada arsip statistik tetapi juga kepada arsip dinamis, jadi mulai dari awal sampai hulu sudah diatur dalam Undang-Undang tersebut.

Arih Murwati bahwa sesuai dengan amanat pasal 12 Undang-Undang Nomor 43 Tahun 2009 tentang kearsipan, Arsip Nasional Republik Indonesia membangun Sistem Kearsipan Nasional untuk memberiakn Informasi yang autentik dan utuh dalam mewujudkan arsip sebagai tulang punggung manajemen penyelenggaraan negara, memori kolektif bangsa dan simpul pemersatu bangsa dalam kerangka Negara Kesatuan Republik Indonesia.

\section{METODE :}

\section{Metode yang digunakan adalah Metode Kualitatif.}

Metode Kualitatif merupakan Metode Penelitian Naturalistik karena penelitiannya dilakukan pada kondisi yang alamiah karena data atau dokumen yang terkumpul dan analisisnya lebih bersifat kualitatif. Analisis data yang dilakukan bersifat induktif berdasarkan fakta-fakta yang ditemukan di lapangan dan kemudian dikonstruksikan menjadi hipotesis atau teori.

Metode tersebut dimaksudkan untuk mempelajari dan meneliti bagaimana pelaksanaan berdasarkan Implementasi Sistem Pengelolaan Kearsipan yang Evektif.

Lokasi Penelitian berada di Sekolah Usaha Perikanan Menengah Sorong yang beralamat di Jalan Jenderal Ahmat Yani No.32 Kelurahan Klakublik Kota Sorong Provinsi Papua Barat.

\subsection{Jenis dan Sumber Data}

Jenis dan Sumber Data terdiri dari :

1. Data Primer adalah data yang di peroleh langsung dari lapangan disamping dokuen tertulis, biasanya didapatkan dari subjek penelitian dengan cara melakukan pengamatan, percobaan atau wawancara langsung dengan responden.

2. Data Sekunder adalah data yang tidak langsung diperoleh dari sumber pertama, dan telah tersusun dalam bentuk dokumen tertulis. Data-data yang digunakan adalah melalui buku-buku referensi serta Peraturan Perundang-Undangan yang ada relevansinya dengan objek yang akan dibahas, data sekunder ini akan diperoleh dengan berpedoman pada literatur-literatur sehingga dinamakan penelitian kepustakaan. 
Penelitian Kepustakaan adalah penelitian yang dilakukan dengan mempelajari bahan-bahan hukum yang berkaitan dengan data sekunder yang terdiri dari :

1. Undang-Undang Nomor 43 Tahun 2009 tentang Kearsipan

2. Peraturan Menteri KP Nomor : 52/PERMENKP/2014 tentang Kearsipan

3. Peraturan Menteri KP Nomor : 53/PERMENKP/2014 tentang Pedoman Umum Tata Naskah Dinas

4. Majalah Kearsipan

\section{HASIL DAN PEMBAHASAN}

Dalam menghadapi tantangan diera globalisasi sekaligus mendukung terwujudnya penyelenggaraan pemerintahan yang baik dan bersih, serta peningkatan kualitas pelayanan publik, penyelenggaraan kearsipan di lembaga pemerintahan dan lembaga pendidikan, perusahaan, organisasi politik, organisasi kemasyarakatan dan perseorangan harus dilakukan dalam suatu sistem penyelenggaraan kearsipan yang komprehensif dan terpadu. Sementara disisi lain ketentuan dan pengaturanyang berkaitan dengan penyelenggaraan kearsipan masih bersifat parsial dan tersebar dalam berbagai peraturan perundang-undangan sehingga perlu diatur secara komprehensif dalam suatu undang-undang tersendiri.

Kearsipan yang ada di Unit Kerja Teknis Sekolah Usaha Perikanan Menengah Sorong telah di tangani oleh pengelola kearsipan yang tugasnya mengolah, menata, mengidentifikasi terhadap arsip-arsip yang sudah sampai 10 Tahun seperti arsip-arsip umum yang waktunya sudah harus di musnahkan agar tidak tertumpuk pada box file, lemari dan ruangan arsip. Merujuk ke pemusnahan arsip harus berpedoman pada ketentuan dan peraturan yang berlaku, karena tidak semudah pemusnahan naskah maupun dokumen pada lembaga pemerintah dan lembaga pendidikan yang tidak merujuk pada peraturan dan perundangundangan yang berlaku.

Sistimatika pengelolaan kearsipan pada Sekolah Usaha Perikanan Menengah Sorong berpedoman pada Peraturan Menteri Kelautan dan Perikanan, dan telah sesuai dengan Standar Operasional Prosedur (SOP) Kearsipan.

Adapun pengelolaan arsip yang dilakukan oleh staf pengelola kearsipan pada Sekolah Usaha Perikanan Menengah Sorong meliputi :
Pengelolaan Arsip Dinamis (Aktif dan Inaktif), yakni Penciptaan Arsip, Penggunaan dan Pemeliharaan arsip, Penyusutan arsip, untuk mendukung pengelolaan arsip Dinamis yang efektif dan efisiens, pencipta arsip membuat klasifikasi arsip, jadwal retensi arsip, serta sistem klasifikasih keamanan dan akses arsip. Pengelola kearsipan juga terbukti bertanggung jawab untuk menjaga kerahasiaan, keautentikan, keutamaan, dan keselamatan arsip yang di kelolanya.

Pelaksanaan Pengelolaan Arsip Dinamis

1. arsip yang autentik, utuh terpercaya sesuai dengan peraturan perundang-undangan

2. Penciptaan arsip dilaksanakan berdasarkan analisis tugas dan fungsi organisasi pencipta arsip

3. Penciptaan arsip harus memenuhi komponen struktur, isi dan konteks arsip

4. Untuk memenuhi ketentuan peraturan perundangan yang berlaku, pencipta arsip mengatur dan mendokumentasikan proses pembuatan dan penerimaan arsip secara akurat penggunaannya.

5. Penciptaan arsip telah dilaksanakan dengan baik dan benar sehingga menghasilkan Dan Pemeliharaan Arsip Dinamis yakni Pencipta arsip wajib menyediakan arsip dinamis bagi kepentingan arsip yang berhak

6. Penyusutan Arsip yakni untuk meningkatkan efisiensi dan efektifnya pengelolaan kearsipan wajib melakukan upaya penyusutan arsip adalah sebagai berikut Penyusutan arsip dilaksanakan oleh pencipta arsip, Penyusutan arsip dilaksanakan berdasarkan Jenis Retensi Arsip dengan memperhatikan kepentingan, pencipta arsip yang ada pada unit pelaksana teknis.

7. Ketentuan mengenai penyusutan arsip diatur dengan peraturan pemerintah yakni Kementerian Kelautan dan Perikanan.

8. Pemindahan Arsip yakni untuk jenis-jenis arsip yang sudah tergolong dalam arsip inaktif oleh unit kerja pencipta arsip sesuai dengan peraturan perundangan yang berlaku, maka unit pencipta arsip wajib melaksanakan Pemindahan arsip inaktif dari pengolah ke unit kearsipan, Pemusnahan arsip yang telah habis retensi dan yang tidak memiliki nilai guna yang di laksanakan

9. sesuai dengan ketentuan dan peraturan yang berlaku. 
Sistem pemberkasan kearsipan di Unit Kerja Teknis Sekolah Usaha Perikanan Menengah Sorong adalah sistem pemberkasan berdasarkan subyek yang dilakukan dengan sistem penyimpanan arsip berdasarkan permasalahan topik atau pokok masalah yang sesuai dengan tugas dan fungsi organisasi yang jenis arsipnya lebih mudah disajikan dengan menyebut nama subyek. Disamping itu sistem pemberkasan berdasarkan subyek dapat diterapkan untuk menata arsip-arsip korespondensi.

Pola penanganan arsip secara sentralisasi atau terpusat yakni tempat penanganan dan penyimpanan arsip pada satu bagian yaitu dibagian Tata Usaha dan sekertariat. Dalam penanganan arsip menggunakan kartu Kendali atau buku kendali. kegunaan dari kartu kendali atau buku kendali ini untuk memudahkan pencari dari masing-masing bagian yang mempunyai arsip tersebut untuk ditemukan oleh arsiparis.

Pola penanganan arsip secara desentralisasi yaitu pola yang dilakukan oleh masing-masing bagian yang mempunyai arsip, baik itu penyusutan dan penyimpanan. dari pola ini setiap bagian-bagian akan mempunyai tempat penyimpanan arsip sendiri.

Adapun penerapan sistem pemberkasan berdasarkan subyek dapat dilaksanakan secara konsisten, logis dan sistimatis. Maka perlu dibuatkan bagan/pola klasifikasi yang berupa daftar pengelompokan subyek yang dibuat secara berjenjang dan disusun berdasarkan tugas dan fungsi organisasi.

Pemberkasan arsip dilakukan tanpa menunggu volume arsip banyak dan menumpuk untuk segerah disimpan, sehingga tidak akan akan menyulitkan dalam penataannya. Meneliti arsip juga untuk menetapkan apakah arsip sudah layak untuk disimpan, juga meneliti apakah lampiran-lampirannya lengkap sebagaimana dimaksud, serta menetapkan apakah perlu disimpan bersama menjadi satu dengan suratnya, ataukah disimpan sendiri karena bentuk fisiknya tidak memungkinkan untuk disimpan.

Penyelenggaraan kearsipan bertujuan untuk menjamin terciptanya arsip dari kegiatan yang dilakukan oleh Lembaga Negara, Pemerintah dan Lembaga Pendidikan, menjamin ketersediaan arsip yang autentik dan terpercaya sebagai alat bukti yang sah, dan menjamin terwujudnya pengelolaan arsip yang andal dan pemanfaatan arsip sesuai dengan ketentuan perundang-undangan.

Penyelenggaraan kearsipan dilaksanakan berasaskan Kepastian hukum, Keautentikan dan keterpercayaan, Keutuhan, Asal usul (principle of provenance), Aturan asli (principle of original order), Keamanan dan keselamatan, Keprofesionalan, Akuntabilitas, Kemanfaatan, dan Kepentingan umum.

Fungsi kearsipan dalam suatu lembaga atau instansi pemerintah adalah dapat menyimpan semua surat atau naskah selama diperluhkan, dapat menyiapkan surat atau naskah setiap kali diperluhkan, dapat menyiapkan surat atau naskah yang diperluhkan menjadi satu, sehingga merupakan suatu riwayat hidup yang lengkap.

Peralatan yang digunakan dalam sistem kearsipan sebagai penyimpanan dan penemuan kembali arsip adalah sebagai berikut :

\section{Filing Cabinet}

Filing cabinet terdiri dari laci-laci yang digunakan untuk menyimpan dokumen atau surat naskah yang telah menjadi arsip.

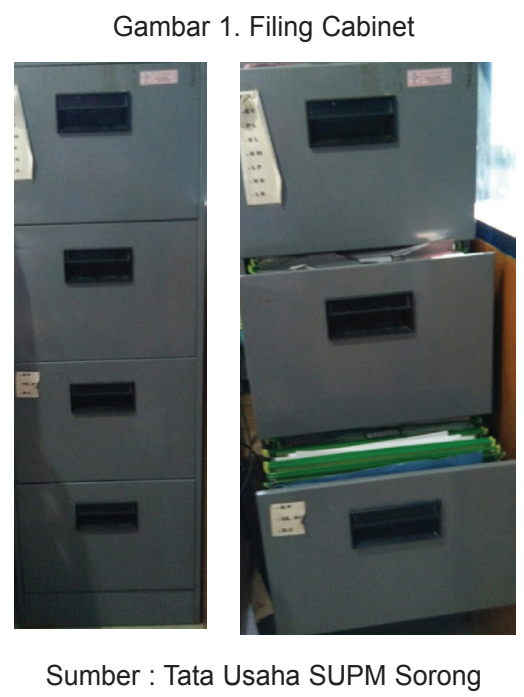

\section{Guide}

Guide sebgai pembatas unutk memisahkan arsip berdasarkan jenisnya, sesuai sistem penyimpanan arsip yang digunakan. Biasanya guide dilengkapi dengan tab untuk mencantumkan pokok masalah atau kode-kode klasifikasi arsip.

\footnotetext{
Gambar 2. GUIDE ARSIP

Pembatas dalam Penyimpanan Arsip
}

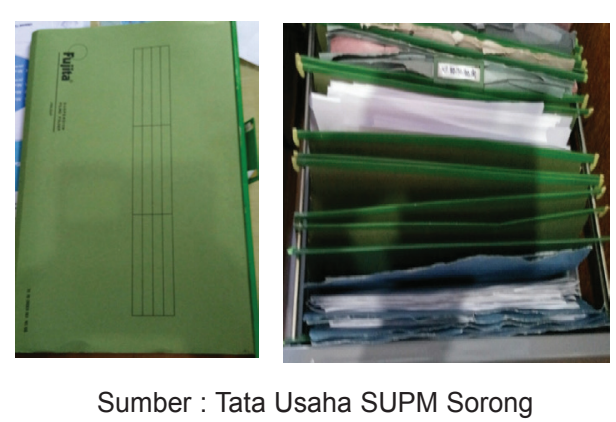




\section{Map Gantung Hanging Folder}

Map gantung merupakan tempat atau folder yang digunakan untuk menyimpan dokumen arsip. Jika kita menyimpan arsip dalam lemari arsip atau filing cabinet, dapat menggunakan hanging folder atau map gantung.

Gambar 3. Map Gantung Menyimpan arsip pada Filing Cabinet
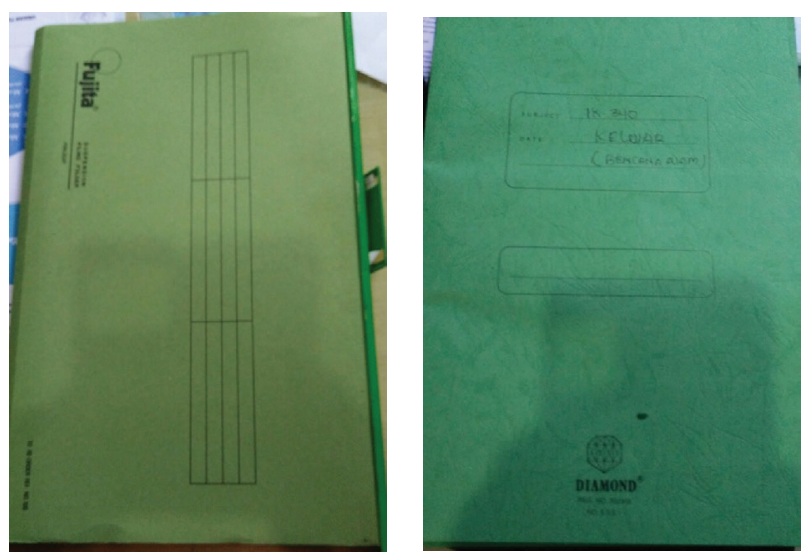

Sumber : Tata Usaha UPM Sorong

\section{Ordner}

Ordner merupakan map untuk penyimpanan dokumen arsip, yang juga menggunakan lemari kayu, kaca maupun alumenium, dalam ordner dilengkapi dengan besi untuk mengikat arsip yang telah diberi lubang sebelumnya.

Gambar 4. ORDNER FILE

Penyimpanan Arsip yang Telah di Bolong
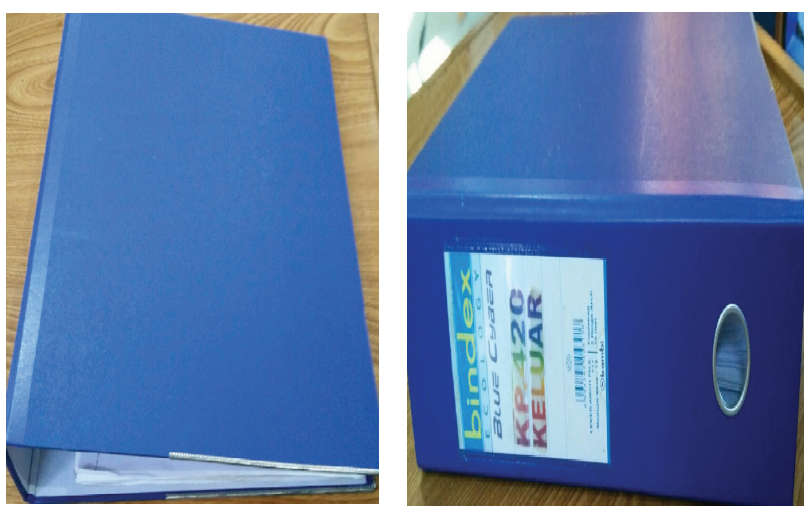

Sumber : Tata Usaha SUPM Sorong

\section{Buku arsip}

Buku arsip digunakan untuk mencatat semua surat yang telah selesai diproses baik itu surat masuk maupun surat keluar. Buku arsip berfungsi sebagai pedoman dalam penyimpanan arsip
Gambar 5. BUKU ARSIP

Mencatat Surat Masuk Dan Keluar Telah Selesai di Proses
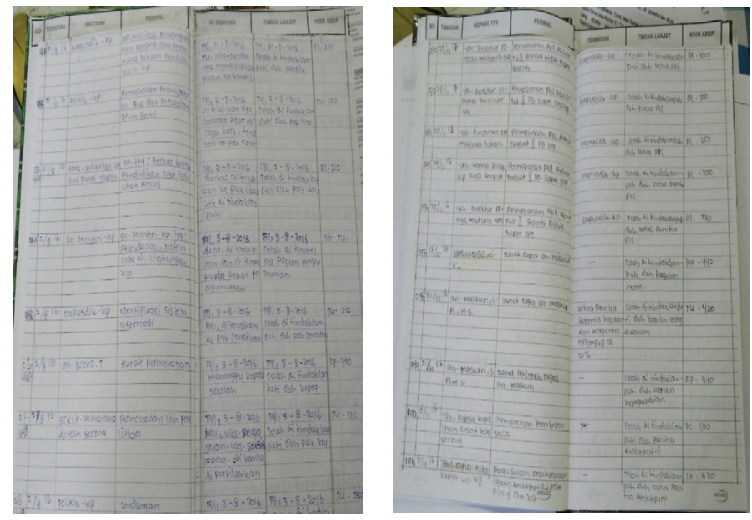

Sumber : Tata Usaha SUPM Sorong

\section{Komputer}

Komputer merupakan alat untuk menyimpan dan mengelola arsip dalam bentuk digital.

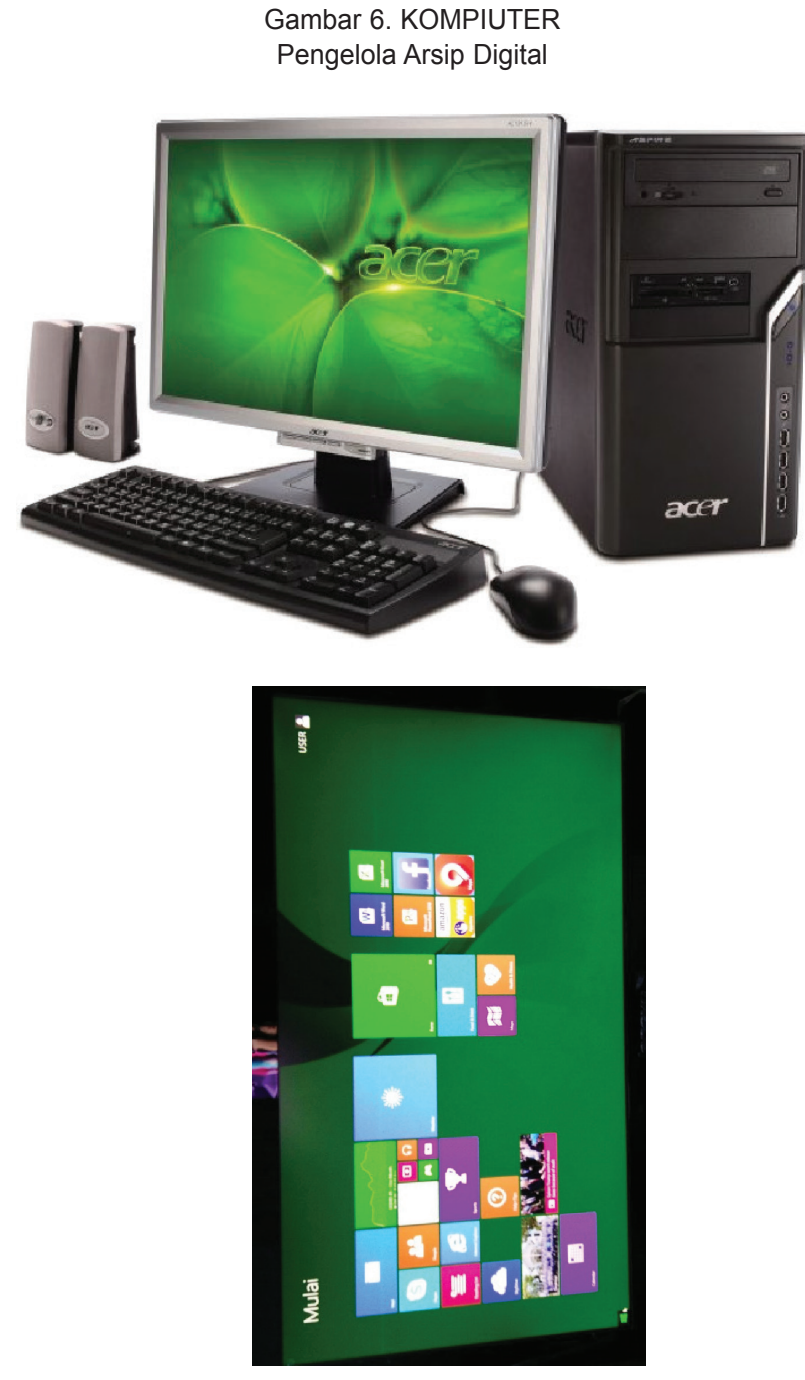

Sumber : Tata Usaha SUPM Sorong 


\section{Scanner}

Scanner merupakan alat untuk memindai dokumen yang akan disimpan secara digital.

Gambar 7. Scanner

Mengkopi arsip secara digital

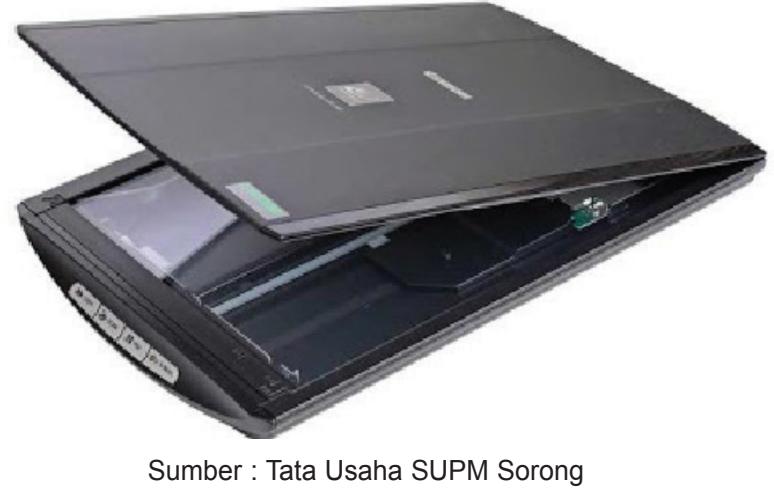

Langkah-langkah kearsipan atau prosedur penyimpanan arsip adalah sebagai berikut :

1. Pengumpulan dokumen atau surat yang berasal dari berbagai unit organisasi yang dikumpulkan pada bagian kearsipan

2. Memeriksa dan menyortir atau memilah-milah dokumen yang akan disimpan apakah sudah siap disimpan atau belum, petugas kearsipan memerikasa tanda atau perintah simpan (relase mark) yang menunjukan surat atau dokumen tersebut sudah benar-benar akan disimpan yang diberikan kode bahwa telah selesai diproses dan diarsipkan.

3. Mengindeks merupakan kegiatan menentukan kata tangkap yang digunakan sebagai identitas surat yang disimpan

4. Memberi kode merupakan kegiatan menuliskan kode pada surat atau pada kolom yang sudah tersediah di dalam lembar disposisi, kode tersebut diambil dari kata tangkap yang telah diindeks

Tabel 1. Memberikan Kode Surat. Memberikan kode pada Arsip Surat

\begin{tabular}{|c|c|c|c|c|}
\hline No & Nama surat & \multicolumn{2}{|c|}{ Bentuk Kode } & Ket \\
\hline 1. & Undangan & TU & 330 & Arsip \\
\hline 2. & MOU & KU & 440 & Arsip \\
\hline 3. & Cuti Pegawai & KP & 610 & Arsip \\
\hline
\end{tabular}

Sumber : Tata Usaha SUPM Sorong

Tujuan utama pemberkasan arsip adalah untuk memudahkan penemuan kembali berkas secara cepat dan tepat apabila sewaktu-waktu diperlukan.
Maksud dan tujuan ditetapkannya sistem pemberkasan arsip di Sekolah Usaha Perikanan Menengah Sorong adalah sebagai petunjuk untuk melaksanakan penyimpanan dan penyusutan arsip berdasarkan sistem pemberkasan subyek dan jenisjenis peralatan yang digunakan serta menunjang terlaksananya penyusunan arsip yang berdaya guna dan berhasil guna.

Langkah-langkah pemberkasan meliputi pemeriksaan berkas, pengelompokan berkas dalam folder, penentuan indeks, pengkodean, tunjuk silang, penyortiran dan penyimpanan berkas serta memasukan arsip dalam folder.

Pemeriksaan berkas dilakukan untuk mengetahui apakah suatu berkas surat sudah siap untuk disimpan, setelah dilakukan pemeriksaan berkas surat dan dapat dipastikan bahwa berkas surat tersebut siap untuk disimpan.

Pengelompokan Berkas Arsip dalam Folder dilakukan agar arsip tertata dengan baik dan rapih agar sewaktu-waktu mudah ditemukan kembali.

Tabel 2. Bentuk seri. Sebagai Pedoman dalam memberikan kode pada dokumen arsip

\begin{tabular}{|c|c|c|c|c|}
\hline No & Nama surat & \multicolumn{2}{|c|}{ Bentuk Kode } & Ket \\
\hline 1. & Undangan & TU & 330 & Arsip \\
\hline 2. & MOU & KU & 440 & Arsip \\
\hline 3. & Cuti Pegawai & KP & 610 & Arsip \\
\hline
\end{tabular}

Sumber : Tata Usaha SUPM Sorong

Penyortian berkas surat dalam filing sistem subyek dilakukan berdasarkan subyek utama, sub subyek serta rinciannya atau melalui kode-kode yang ditetapkan dalam pola klasifikasi surat.

Tabel 3. Bentuk berkas surat Mencatata Dokumen Surat

\begin{tabular}{|c|c|c|c|c|c|c|}
\hline \multirow{2}{*}{ No } & \multirow{2}{*}{$\begin{array}{c}\text { Tgl } \\
\text { masuk }\end{array}$} & \multirow{2}{*}{$\begin{array}{c}\text { Alamat } \\
\text { pengirim }\end{array}$} & \multicolumn{4}{|c|}{ Dari Surat Masuk } \\
\hline & & & $\operatorname{tgl}$ & No surat & Perihal & Kode \\
\hline 001 & $17 / 3 / 17$ & BRSDM & $27 / 2 / 17$ & $\begin{array}{c}161 / \\
\text { BRSDM/ } \\
\text { I/ } 17\end{array}$ & $\begin{array}{c}\text { Surat } \\
\text { Edaran }\end{array}$ & TU.210 \\
\hline
\end{tabular}

Sumber : Tata Usaha SUPM Sorong

Langkah-langkah penemuan kembali arsip, jika arsip diperlukan atau digunakan maka akan terjadi proses pencarian atau penemuan kembali arsip, jika ada pihak yang ingin menggunakan arsip atau melakukan proses penemuan kembali arsip, maka langkah-langkah yang harus dilakukan adalah 
1. Mengetahui jenis arsip yang ingin digunakan atau di cari.

2. Menentukan kode berdasarkan nama yang diindeks

3. Menentukan kode berdasarkan kode klasifikasi pada surat atau naskah.

4. Mengambil arsip dari tempat penyimpanan dan mengantinya dengan bon pinjaman arsip atau out

5. slip jika dipinjam 1 lembar arsip, jika yang dipinjam 1 folder maka harus dibuat out folder.

Sistem Nomor Berdasarkan Subyek. Suatu sistem nomor yang menekankan subyek sebagai pedoman penomorannya, sistem ini menggunakan nomor secara berurutan untuk menentukan kode dari subyek tertentu. Dalam penomoran dapat menggunakan angka seluruhnya (perenomorik) atau gabungan huruf dengan angka (alphanomorik). Misalnya :

Undangan $=\mathrm{TU} .330$

Sistem subyek atau masalah sistem (kode klasifikasi) penyimpanan dan penemuan kembali arsip berdasarkan masalah atau pokok isi surat, sistem masalah ini bisa diambil dari perihal surat atau bidang usaha, dalam hal ini surat-surat berdasarkan perihal surat, misalnya surat yang berhubungan dengan kelompok surat keputusan penerimaan peserta didik baru di simpan di kelompok Surat Keputusan (SK) dan sebagainya.

Daftar klasifikasi dalam kearsipan merupakan suatu pedoman untuk pemberian kode arsip sekaligus merupakan pedoman penyimpanan dan penemuan kembali arsip. Khusus dalam kearsipan sistem masalah daftar kalsifikasi dibuat dahulu dan ditetapkan oleh organisasi unit dijadikan sebagai pedoman, untuk organisasi yang kecil biasanya klasifikasinya berdasarkan masalah utama dan sub masalah, sedangkan untuk organisasi yang besar klasifikasi dibuat berdasarkan masalah utama, sub masalah dan sub-sub masalah.

Tabel 4. Sistem Masalah

\begin{tabular}{|c|c|c|c|}
\hline No & $\begin{array}{c}\text { Masalah } \\
\text { Subyek }\end{array}$ & Masalah Utama & $\begin{array}{c}\text { Sub } \\
\text { Masalah }\end{array}$ \\
\hline 1. & Kepegawaian & Kenpat Pegawai & KP \\
\hline 2. & Keuangan & Keuangan & KU \\
\hline 3. & Tata Usaha & Undangan & TU \\
\hline 4. & HUMAS & Pelayanan publik & HM \\
\hline
\end{tabular}

Sumber : Tata Usaha SUPM Sorong
Penyusutan arsip adalah memindahkan arsip inaktif dari unit pengelola ke unit kearsipan dalam lingkungan intern organisasi, pemusnahan arsip juga harus sesuai dengan ketentuan yang berlaku dan menyerahkan arsip statis dari unit kearsipan ke Arsip Nasional Republik Indonesia (ANRI).

Penyusutan arsip juga dapat di lakukan dengan 3 cara yaitu :

\section{- Retensi}

Retensi adalah penyusutan arsip yang dilakukan berdasarkan jadwal retensi yang dimiliki oleh arsiparis, dimana setiap arsip akan dimusnahkan atau dipindahkan apabila telah memasuki masa retensinya.

\section{- Periodik}

Periodik merupakan suatu penyusutan atau pemusnahan arsip berdasarkan jadwal retensi yang telah dibuat atau berdasarkan pentingnya arsip. Hal ini dilakukan setahun sekali.

\section{- Per Proyek}

Per Proyek merupakan suatu penyusutan arsip tentang suatu proyek, apabila proyek tersebut telah selesai maka semua arsip tersebut disusun berdasarkan urutan tanggal (kronologis kemudian disatukan dengan tali atau box untuk kemudian disimpan pada gudang arsip.

Tujuan penyusutan arsip agar arsip tidak menumpuk pada ruangan arsip, menjamin tersedianya informasi yang benar-benar berguna, efisiensi dan efektif, dan menjamin keselamatan bahan bahan pertanggung jawaban yang sah.

Teknik penyusutan berdasarkan jadwal retensi arsip, non jadwal retensi arsip. Tujuan dari jadwal retensi arsip yaitu penyisihan arsiparsip dengan tepat bagi arsip-arsip yang tidak memiliki jangka waktu simpan, penyimpanan sementara arsip-arsip yang tidak diperlukan bagi kepentingan administrasi, pemeliharaan arsiparsip yang bernilai permanen.

Penyusunan jadwal retensi arsip agar kegiatan yang perlu dilakukan dalam menentukan jangka waktu retensi arsip meliputi kegiatankegiatan inventarisasi dan menilai kegunaan arsip 
Tabel 5. JADWAL RETENSI ARSIP

Membantu dalam Penyusutan Arsip

\begin{tabular}{|c|c|c|c|c|c|}
\hline \multicolumn{2}{|c|}{ Pokok } & \multirow{2}{*}{ Perincian } & \multirow{2}{*}{ Jangka waktu penyimpanan } & \multicolumn{2}{c|}{ Nilai } \\
\cline { 4 - 6 } & & Sementara & Permanen \\
\hline Kepeg & Kenpat & Ujian Kenpat & Aktif 2 Thn & $\mathrm{v}$ & \\
\hline Keuangan & Gaji & Daftar gaji PNS & Aktif 10 -20 thn & & $\mathrm{v}$ \\
\hline Tata Usaha & Und & Und. rakernis & Aktif 3 thn & $\mathrm{v}$ & \\
\hline Kesiswaan & Surat ket & surat ket. Benar peserta didik & Aktif 2 thn & $\mathrm{v}$ & \\
\hline
\end{tabular}

Sumber : Tata Usaha SUPM Sorong

\section{KESIMPULAN}

Pelaksanaan sistem kearsipan yang efektif dan efisien meliputi tahapan-tahapan yang saling berkaitan antara Tata Naskah Dinas dan Tata Kearsipan, dan saling mendukung serta saling menjelaskan sehingga penanganan arsip secara baik, terencana, konsepsional dan secara profesional. Pengelolaan arsip merupakan bagian dari pada wawasan dan ruang lingkup sistem informasi manajemen. Keberhasilan pelaksanaan manajemen arsip akan mencapai hasil yang baik bilamana ditunjang dengan ketersediaan fasilitas dan teknologi informasi kearsipan yang handal.

\section{SARAN}

Dalam pembuatan Jurnal Ilmiah ini masih jauh dari kesempurnaan, sehingga kritik yang membangun sangat diharapkan oleh penulis agar menjadi pedoman bagi penulis jurnal ilmiah berikutnya.

\section{UCAPAN TERIMA KASIH}

Terima Kasih penulis ucapkan kepada Bapak MASKURI, S.Pi.,M.Si selaku Kepala Sekolah yang mengijinkan penulis untuk membuat jurnal ilmiah ini sehingga dapat terlaksana sesuai jadwal yang ditentukan.

Terima kasih penulis ucapkan kepada Bapak Rasman, S.Pi selaku Kasuubag Tata Usaha yang selalu mengingatkan penulis dalam membuat jurnal ilmiah ini agar terlalsana sesuai jadwal yang ditentukan.
Terima Kasih juga penulis ucapkan kepada Tenaga Pendidik dan Tenaga Kependidikan pada SUPM Sorong yang telah membantu dan memberikan ide-ide, maupun suport sehingga penulis membuat jurnal ilmiah ini dapat berjalan sesuai jadwal yang ditentukan dari Sekretaris Badan Riset dan Sumber Daya Manusia Kelautan dan Perikanan.

\section{DAFTAR PUSTAKA.}

Abubakar, Radi. 1997. Cara-cara Pengelolaan Kearsipan yang Praktis dan Efisien, Jakarta

Abubakar, Radi. 1991. Pola Kearsipan Modern : Sistem Kartu Kendali. Jakarta

Martono, Boedi. 1994. Peanataan Berkas dalam Manajemen Kearsipan. Jakarta. Sinar Harapan

Soedjodi, Drs, F.X, MPA, (1995), Organisasi dan Metode, Jakarta

Wursanto, Ig. 1991. Himpunan Peraturan Perundang-undangan tentang Kearsipan. Yogyakarta. 


\section{GAMBAR LEMARI ARSIP \\ SURAT MASUK DAN SURAT KELUAR \\ SERTA ARSIP KEPEGAWAIAN}

5. SURAT KELUAR

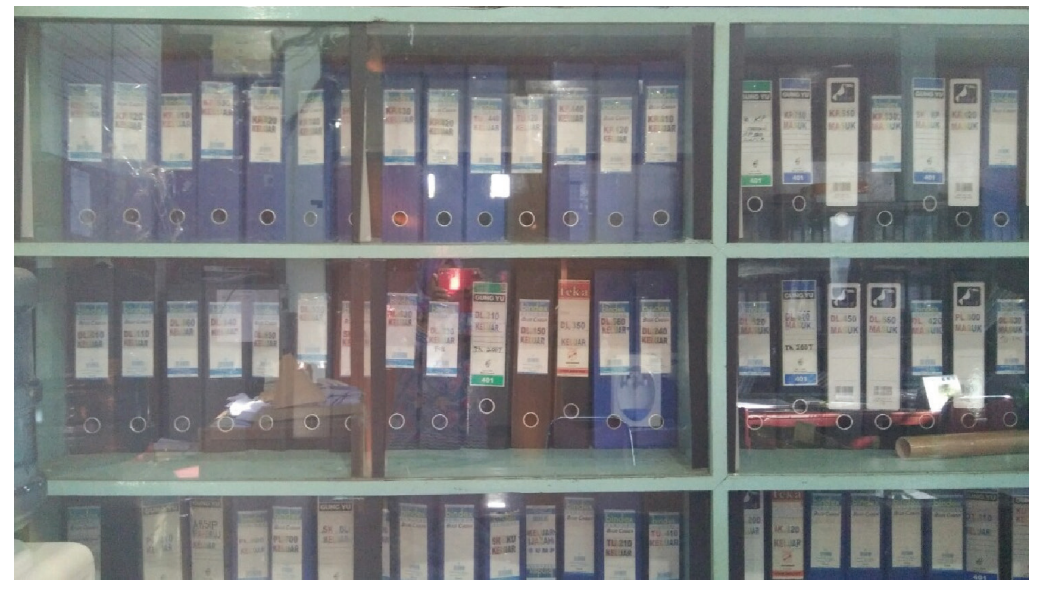

6. SURAT KELUAR
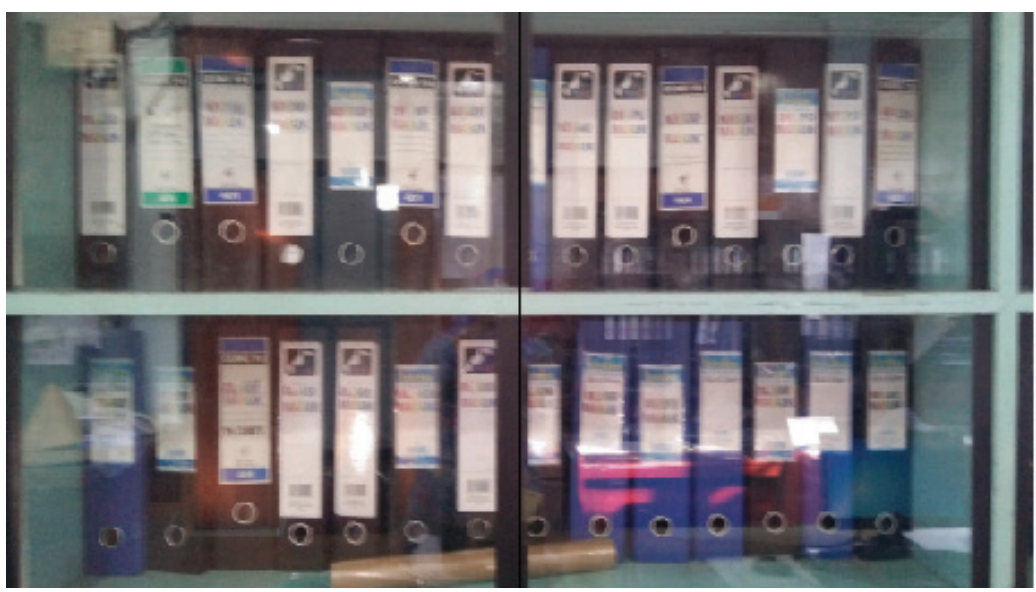

7. ARSIP KEPEGAWAIAN

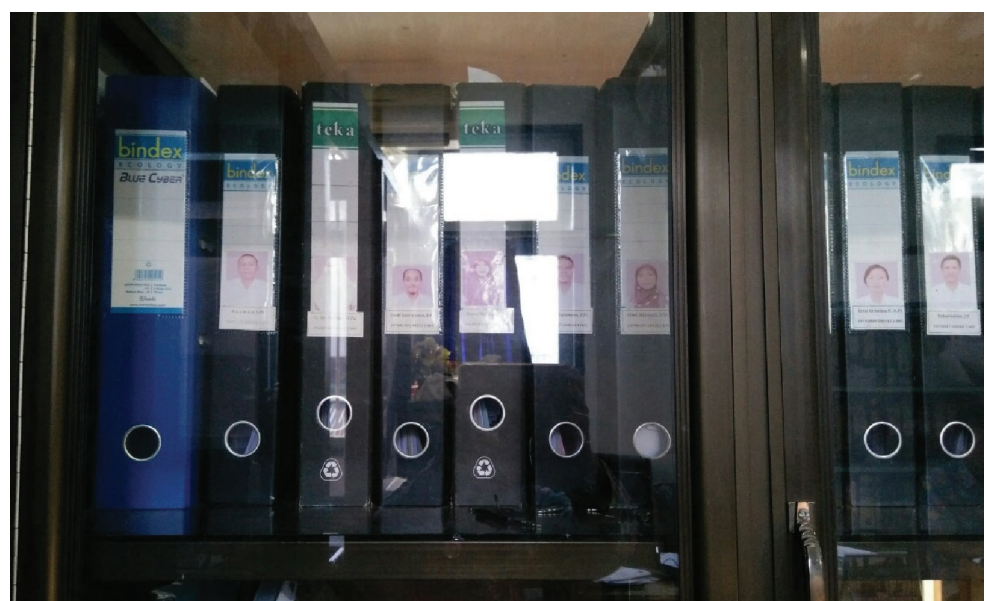

